\title{
Thresholds of irradiance for seagrass Posidonia oceanica meadow metabolism
}

\author{
E. Gacia ${ }^{1, *}$, N. Marbà ${ }^{2}$, J. Cebrián ${ }^{3,4}$, R. Vaquer-Sunyer ${ }^{2}$, N. Garcias-Bonet ${ }^{2}$, \\ C. M. Duarte ${ }^{2,5}$
}

${ }^{1}$ Biogeodynamics and Biodiversity Group, Centre d'Estudis Avançats de Blanes, Consejo Superior de Investigaciones Cientificas (CEAB-CSIC), Blanes 17300, Spain

${ }^{2}$ Department of Global Change Research, Mediterranean Institute for Advanced Studies (IMEDEA; UIB-CSIC), Miquel Marqués 21, Esporles 07190, Spain

${ }^{3}$ Dauphin Island Sea Lab, 101 Bienville Blvd, Dauphin Island, Alabama 36528, USA

${ }^{4}$ Department of Marine Sciences, University of South Alabama, Mobile, Alabama 36688, USA

${ }^{5}$ The UWA Oceans Institute, The University of Western Australia, 35 Stirling Highway, Crawley 6009, Western Australia, Australia

\begin{abstract}
Meadows of the endemic seagrass Posidonia oceanica are threatened in the Mediterranean due to a general deterioration of the light environment that becomes critical when light irradiance is insufficient to meet the carbon requirements of the system. Here, we conduct a $3 \mathrm{wk}$, in situ shading experiment (8 levels plus controls) to determine the threshold of irradiance for balanced metabolism in a shallow $P$. oceanica meadow and further assess the recovery of the system 1 wk later. Reduced light irradiance decreased the net community production of the meadow, which may turn negative (i.e. respiration exceeded gross community primary production) under $338 \mu \mathrm{E} \mathrm{m}^{-2} \mathrm{~s}^{-1}$. Shading throughout the experiment did not appear to cause sustained physiological damage to the system since values of net community production after the cessation of shading were similar to pre-experimental, ambient levels. Sediment acid volatile sulfide pools ranged between 0.002 and $0.058 \mathrm{~mol} \mathrm{~m}^{-2}$ across shading treatments, and the highest pools were observed in the most shaded sediments. At high light impairment, meristematic cell divisions were low, and carbohydrate content in young rhizomes decreased throughout the experiment. Eight days after the cessation of shading, reduced rhizome carbohydrate stores and elevated sediment sulfide levels still persisted in the previously intensively shaded areas. The present study provides evidence of resistance and resilience of the seagrass Posidonia oceanica to light impairment for short ( $3 \mathrm{wk}$ ) periods of time. Although the compensation irradiance of the system varied by $\sim 2$-fold, it provides a quantitative estimate of the irradiance threshold at which seagrass meadows may shift from being coastal carbon sinks to $\mathrm{CO}_{2}$ sources.
\end{abstract}

KEY WORDS: Seagrass - Ecosystem - Production - Respiration - Compensation Irradiance · Mediterranean

Resale or republication not permitted without written consent of the publisher

\section{INTRODUCTION}

Seagrass communities are highly productive ecosystems, rivaling the most productive ecosystems on Earth (Duarte \& Chiscano 1999). However, they also support high respiratory demands by the lush micro- bial and animal communities they harbor, reflected in high decomposition and herbivory rates in seagrass meadows (Cebrián \& Duarte 1998, Prado et al. 2010). Yet, seagrass ecosystems tend to be autotrophic, with gross primary production exceeding ecosystem respiratory demands (Gattuso et al. 1998, 
Barrón et al. 2006, Duarte et al. 2010), and act, therefore, as inorganic carbon sinks (Duarte et al. 2010). However, seagrass meadows can become heterotrophic ecosystems when net primary production decreases as a consequence of reduced water transparency, i.e. shading (Duarte 1995, Gacia et al. 2005) and becomes smaller than ecosystem respiration. Depending on light availability, therefore, seagrass meadows may shift from being coastal carbon sinks and oxygen sources to $\mathrm{CO}_{2}$ sources and oxygen sinks.

The shift from autotrophic to heterotrophic seagrass communities as a result of deteriorating light environment occurs at the threshold irradiance for the metabolic balance of seagrass ecosystems, defined as the irradiance at which gross primary production equals community respiration (R). Resolving this threshold is important for the maintenance of this key function of the ecosystem. Moreover, changing from autotrophic to heterotrophic ecosystem metabolism results in a general decrease of the oxygen concentration in the water column, particularly around the seagrass canopy and water-sediment interface. If these conditions prevail, the seagrass and associated species may suffer from stress associated with hypoxia or anoxia and with the production and accumulation of sulfide in the rhizosphere (Calleja et al. 2006), which is highly toxic to the plants (Borum et al. 2005). Indeed, shoot meristematic activity of Posidonia oceanica, measured as the percentage of nuclei in G2 phase of the cell cycle, sharply decreases (Garcias-Bonet et al. 2008) and P. oceanica decline accelerates when pore-water sulfide concentration exceeds $10 \mu \mathrm{M}$ (Calleja et al. 2007).

Posidonia oceanica meadows are key endemic Mediterranean ecosystems supporting highly autotrophic communities that act as carbon sinks in the Mediterranean coast (Gacia et al. 2002, Gazeau et al. 2005, Barrón et al. 2006). These meadows are presently declining across the Mediterranean basin (Marbà et al. 2005, Marbà \& Duarte 2010), partially due increasing turbidity in coastal areas because of eutrophication (Duarte 1995), dredging and trawling (Boudouresque et al. 2009). Whereas shading experiments have been conducted to resolve the possible responses of $P$. oceanica to eutrophication-derived shading, these experiments have focused on the effects on plant performance (Ruiz \& Romero 2001, Serrano et al. 2011), but key community-level responses, such as effects on community metabolism, have not yet been assessed. The threshold irradiance for the metabolic balance of the seagrass community can be established experimentally by examining the response of the community metabolism to a gradient of experimentally induced shading, as has been demonstrated for seagrass communities in Southeast Asia (Gacia et al. 2005) and the Gulf of Mexico (Calleja et al. 2006).

We examined the response of community metabolism to experimental shading in a pristine Posidonia oceanica meadow, with the aim of assessing the threshold irradiance for balanced community metabolism. In addition, we examined changes in seagrass health parameters (i.e. meristematic activity and shoot growth) and sediment quality (i.e. sulfide dynamics) along the shading-induced shift in community metabolism for $3 \mathrm{wk}$ and a short term (1 wk) recovery, to gain a better understanding of the diverse effects that shading can have on $P$. oceanica shoots.

\section{METHODS}

\section{Study site and experimental design}

The experiment was conducted in a continuous and dense (mean $\pm \mathrm{SE}=958 \pm 53$ shoots $\mathrm{m}^{-2}$ ) Posidonia oceanica meadow growing at $6 \mathrm{~m}$ depth at Es Cargol, southeast Mallorca, Spain (39¹6.394' N, $3^{\circ} 2.476^{\prime} \mathrm{E}$ ). The study site was located in a pristine area, where the light extinction coefficient at the time of the experiment was $0.093 \mathrm{~m}^{-1}$ (Duarte et al. 2007). On 8 May 2006, we installed 8 shades, each of $2 \times 2 \mathrm{~m}, 0.8 \mathrm{~m}$ above the sediment. The sides of the shades were also covered with shading screens (Fig. 1). Light attenuation by the shading screens was measured at noon on Days 1, 8 and 23 after the beginning of the experiment. Six light treatments were defined (means $\pm \mathrm{SD}$ ): $2 \pm 0.9,12 \pm 2.2,19 \pm 4.7$, $21 \pm 12.5,31 \pm 10.3,76 \pm 6.9,82 \pm 11.8$ and $92 \pm$ $10.6 \%$ of incident light (IL) to reach the seafloor. In addition, 2 unshaded plots (controls, receiving 100\% incident light) were defined in the same meadow. At the center of each plot, we delimited a $1 \times 1 \mathrm{~m}$ area to assess $P$. oceanica community metabolism and seagrass and sediment responses to shading. The shading experiment ran from 9 to 31 May 2006. Then, the shading screens were removed, and the recovery of $P$. oceanica community metabolism together with seagrass and sediment performance were assessed 1 wk later. During the entire experimental period, seawater temperature ranged from 17.8 to $21.0^{\circ} \mathrm{C}$ (C. Duarte unpubl. data) and significantly rose at an average rate of $0.09 \pm 0.008^{\circ} \mathrm{C} \mathrm{d}^{-1}$ (regression analysis, $\mathrm{R}^{2}=0.73, \mathrm{p}<0.0001$. 


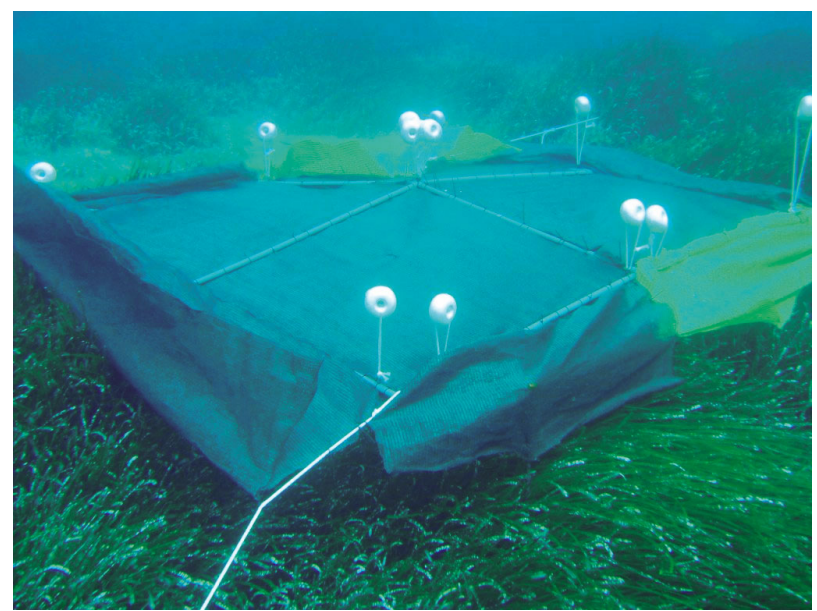

Fig. 1. Experimental shading screen $(2 \times 2 \mathrm{~m})$ with side flaps on the Posidonia oceanica meadow at Es Cargol

\section{Radiation}

Daily radiation in $\mathrm{kJ} \mathrm{m}^{-2}$ was obtained by integrating hourly direct radiation from the Palma airport meteorological station, situated $42 \mathrm{~km}$ from the study site. During the incubations, we also measured surface and underwater irradiance at noon with a Biospherical QSI-140B quantum scalar PAR meter to estimate the light attenuation by the water column and under the screens. The light hours average amount of radiation received during the incubations has been expressed as daily irradiance in $\mu \mathrm{E} \mathrm{m}^{-2} \mathrm{~s}^{-1}$, after converting total daily areal radiation in $\mathrm{kJ} \mathrm{m}^{-2}$ into $\mathrm{W} \mathrm{m}^{-2}$ and this to $\mu \mathrm{E} \mathrm{m}^{-2} \mathrm{~s}^{-1}$ considering the number of photons of $1 \mathrm{~W} \mathrm{~m}^{-2}$ at $555 \mathrm{~nm}$ (factor of 4.15; Kirk 1983).

\section{Community metabolism}

The metabolism of the Posidonia oceanica community subject to the different light treatments was determined in situ using benthic chambers deployed at the center of the different light treatment plots at 1 , 8, 15 and $23 \mathrm{~d}$ after shading started and $1 \mathrm{wk}$ after retrieving the shades to estimate community metabolism recovery. Benthic chambers consisted of transparent gas-tight polyethylene plastic bags (Hansen et al. 2000) of $40 \mathrm{~cm}$ height $\times 25 \mathrm{~cm}$ diameter, attached to a $15.4 \mathrm{~cm}$ diameter PVC ring inserted $10 \mathrm{~cm}$ into the sediment, as described by Barrón et al. (2004). The flexible nature of the polyethylene plastic bags allowed turbulence to propagate in the interior of the benthic chamber, providing mixing within $5 \mathrm{~s}$ (Barrón \& Duarte 2009). Each chamber had 1 sam- pling port to collect water samples at the beginning and end of the incubations with $50 \mathrm{ml}$ syringes. Incubations were done integrating daily hours (initial data from early morning and final data at sunset) and night hours (initial data from sunset and final data at sunrise). Minor deviations from this schedule were corrected for the exact time the incubations lasted in each plot. We acknowledge a possible confinement of the water mass inside the incubation bags resulting in a deviation of the water $\mathrm{O}_{2}$ concentration and $\mathrm{pH}$ from inside the bags with that of the surrounding water, particularly toward late afternoon (Campbell \& Fourqurean 2011) in the high irradiance treatments. To correct for this possible error, we estimated the expected $\mathrm{pH}$ inside the chambers at the end of the daily incubation from the following equation:

$$
\mathrm{pH}=7.61+\left(0.10 \times[\mathrm{DO}] \mathrm{mg} \mathrm{l}^{-1}\right)
$$

with $\mathrm{r}^{2}=0.766(\mathrm{p}<0.0001)$, obtained from a continuous monitoring during daily hours of the 16 May incubation, a day with high light irradiance. This final $\mathrm{pH}$ inside the bags is then compared with the $\mathrm{pH}$ of the surrounding water, and whenever different, the net photosynthesis underestimation is calculated from the $\mathrm{pH}$ values following Invers et al. (1997). Over the course of the experiment, chambers were moved across the central area of the treatment plots, thereby averaging out any potential microscale variability among plots. Daily radiation has been calculated after integrating hourly rates for the time period of the daytime incubations. Changes in dissolved oxygen (DO) concentrations were measured and used to calculate the metabolism of the P. oceanica community along the imposed shading gradient. DO concentrations were determined spectrophotometrically using a modification of the Winkler titration method (Pai et al. 1993, Roland et al. 1999). Absorbance at $430 \mathrm{~nm}$ (Abs430) of the Winkler-fixed samples was measured with a Genesys 5 spectrophotometer and converted to DO concentration using a calibration linear regression: DO $\left(\mathrm{mg} \mathrm{l}^{-1}\right)=(6.7 \times$ Abs430) + 0.0217; $\left.\mathrm{r}^{2}=0.99\right)$. To determine incubation volumes, $2 \mathrm{ml}$ of fluorescent dye (fluorescein) was spiked into each chamber at the end of incubation and allowed to mix for few seconds (see Barrón \& Duarte 2009), and $50 \mathrm{ml}$ of water within the chamber were re-sampled to quantify fluorescein concentration and, from there, estimate chamber volume spectrophotometrically. The calculated volumes ranged between 4 and 8 l. Because $P$. oceanica shoot densities (mean $\pm \mathrm{SE}=958 \pm 53$ shoots $\mathrm{m}^{-2}$; sampling scale $25 \times 25 \mathrm{~cm}^{2}$ ) and biomass dry weight (DW) (mean \pm $\mathrm{SE}=168.3 \pm 24.9 \mathrm{~g} \mathrm{DW}$ shoot $^{-1}$ ) did not vary signifi- 
cantly across the experimental plots (ANOVA, p > $0.05)$, nor did initial epiphyte biomass $(97.2 \pm 7.4 \mathrm{mg}$ DW shoot ${ }^{-1}$; ANOVA p > 0.05), we assumed that similar $P$. oceanica biomass was incubated in the chambers across plots.

Gross community primary production (GCP), Respiration (R), and net community production (NCP) were estimated from the changes in DO concentrations during incubation periods at each treatment plot. Hourly rates of R and NCP were estimated from the difference in oxygen concentration in the chambers during the night and day, respectively. Hourly rates of GCP were estimated from the sum of hourly rates of R and NCP, and daily rates of GCP were calculated by multiplying the hourly GCP by the photoperiod. Daily rates of $\mathrm{R}$ were calculated using the hourly R multiplied by $24 \mathrm{~h}$, and daily rates of NCP were estimated as the difference between daily GCP and $\mathrm{R}$. The resulting $\mathrm{R}$ somewhat underestimated community $\mathrm{R}$ as it does not account for the fraction of anaerobic $\mathrm{R}$ products that are not reoxidized. The underestimation of benthic $\mathrm{R}$ by the use of oxygenbased methods has been calculated to be at most $25 \%$ (Heip et al. 1995), and this bias is likely to be much lower here as sulfate reduction rates were very low in the studied meadow (see 'Results') when compared with those reported for seagrass sediments elsewhere (range 2 to $90 \mathrm{mmol} \mathrm{m}^{-2} \mathrm{~d}^{-1}$; Marbà et al. 2006).

Compensation irradiance $\left(I_{\mathrm{C}}\right)$ for the community metabolism (i.e. $\mathrm{NCP}=0$ ) was estimated from best fitted linear regression equation between NCP and irradiance over the linear range of the relationship (cf. Herzka \& Dunton 1997). This design has been recently considered more appropriate than replicated factorial designs to deliver estimates of such parameters (Duarte et al. 2003). $I_{\mathrm{C}}$ is the threshold irradiance for a community autotrophic-heterotrophic metabolism shift.

\section{Sediment sulfate reduction rate and reducible sulfur pools}

Sulfate reduction rate (SRR) and the acid volatile sulfides (AVS) and total reducible sulfur (TRS, which equals AVS plus chromium reducible sulfur [CRS]) pools in the experimental and control plots were estimated on Days 8, 15 and 23 of the experiment as well as $1 \mathrm{wk}$ after the removal of shading screens. SCUBA divers collected 2 sediment cores per plot, (1) internal diameter (i.d.) $2.6 \mathrm{~cm}$ and (2) i.d. $4.3 \mathrm{~cm}$. The depth of all sediment cores was $10 \mathrm{~cm}$, and they were col- lected avoiding roots or rhizomes. SRR and the AVS and TRS pools were measured in the narrow cores, whereas sediment density, water content and porosity were measured in sediment from the wider ones.

SRR were quantified by the core-injection technique (Jørgensen 1978). Aliquots of $2 \mu \mathrm{l}$ of ${ }^{35} \mathrm{~S}$-sulfate $(70 \mathrm{kBq})$ were injected at $1 \mathrm{~cm}$ intervals through predrilled silicone filled holes, and the cores were incubated at in situ temperature in darkness for 1 to $3 \mathrm{~h}$. After the incubation, the sediment was fixed in $1 \mathrm{M}$ zinc acetate (vol:vol). The samples were stored frozen until distillation according to a 2-step extraction scheme. In the first step, AVS was liberated by the addition of $6 \mathrm{M} \mathrm{HCl}$ (in $50 \%$ ethanol), and in the second step, CRS was extracted by adding $1 \mathrm{M} \mathrm{CrCl}_{2}$ (in $0.5 \mathrm{HCl}$ ); both were trapped in zinc acetate, following Fossing \& Jørgensen (1989). Radioactivity was counted on a Beckman LS-3801 scintillation counter. Sulfate reduction rates $\left(\mathrm{SRR}\right.$, in $\mathrm{nmol} \mathrm{\textrm {cm } ^ { - 3 }}$ $\mathrm{d}^{-1}$ ) were calculated for each sediment core following Fossing \& Jørgensen (1989) as follows:

$$
S R R=\frac{a}{(a+A) t} \times\left[\mathrm{SO}_{4}{ }^{2-}\right] \times 1.06
$$

where $a$ is the total radioactivity in the traps, $A$ is the total radioactivity of the sulfate pool after incubation, $t$ is the incubation time (d), $\left[\mathrm{SO}_{4}{ }^{2-}\right]$ is the sulfate concentration in the sediment $\left(\mathrm{nmol} \mathrm{cm}{ }^{-3}\right)$, and 1.06 is the correction factor for microbial isotope fractionation between ${ }^{32} \mathrm{~S}$ and ${ }^{35} \mathrm{~S}$. Because of the uniformity of sulfate concentration across Posidonia oceanica sediments in Mallorca island $(\mathrm{CV}=4 \%$; Holmer et al. 2003), we used the estimates provided by Marbà et al. (2007). The concentrations of reduced sulfide pools from the traps were determined spectrophotometrically according to Cline (1969).

Sediment density was calculated as the ratio of DW to volume and water content after drying overnight at $105^{\circ} \mathrm{C}$ and reweighing. Porosity was calculated from sediment density and water content.

AVS, TRS and SRR are expressed per area unit $\left(\mathrm{m}^{-2}\right)$, and they integrate the values of the top $10 \mathrm{~cm}$ of sediment.

\section{Seagrass carbohydrate content}

Non-structural carbohydrate content was measured on Days 1, 8 and 23 of the experiment as well as $1 \mathrm{wk}$ after the removal of shading screens following the method described by Alcoverro et al. (1999), based on Yemm \& Willis (1954). Samples of young rhizome (1 $\mathrm{cm}$ from the apex) were ground, extracted 
in hot $\left(80^{\circ} \mathrm{C}\right)$ ethanol and evaporated to dryness at room temperature under a stream of $\mathrm{N}_{2}$. The residual was re-dissolved in distilled water and analyzed spectrophotometrically using a resorcinol assay standardized to sucrose. Starch was extracted from ethanol insoluble residue overnight in $1 \mathrm{~N} \mathrm{KOH}$ and analyzed spectrophotometrically using an anthrone assay standardized to sucrose. Analytical precision, based on the standard deviation of replicates of the internal standard, was $0.05 \%$.

\section{Shoot meristematic activity}

The activity of shoot meristems was analyzed by measuring the percentage of dividing cells at a specific point in time (i.e. noon). Eukaryotic cells have a cell division cycle that comprises the interphase and mitosis phase. The interphase consists of a G1 phase (post-mitotic phase), when the cell grows and synthesizes proteins and RNA, an S phase (DNA synthetic phase), when the DNA is replicated, and a G2 phase, when the cell has doubled the DNA content and the nuclear proteins and is preparing to enter the mitotic phase. The percentage of nuclei in the G2 phase provides information on the percentage of meristematic cells that are dividing and it is used as a proxy of meristematic activity (Garcias-Bonet et al. 2008). The percentage of nuclei in each phase of the interphase (i.e. G1, S and G2) was quantified with flow cytometry techniques as described by Garcias-Bonet et al. (2008).

Posidonia oceanica shoot meristematic activity was measured 1, 8, 15 and 23 d (i.e. end of the shade phase experiment) after the onset of shading experiment and 1 wk after removal of shading screens. Shoot meristematic activity was measured in all treatment plots except 1 (21\% IL); in addition, some activity estimates could not be obtained (see Table S1 in the supplement). In each plot, we collected 6 Posidonia oceanica shoots that were $>25 \mathrm{~cm}$ apart from each other and thus physiologically independent (Marbà et al. 2002). Shoot meristems were processed and analyzed immediately after collection.

\section{Leaf growth rate}

Posidonia oceanica leaf growth rate was measured using the traditional leaf punching technique. At the onset of the shading experiment, we punched the leaves of 10 shoots in each plot just below the junction between the blade and sheath. At the end of the shading experiment, we harvested all marked shoots and quantified the rate of shoot leaf elongation (in $\mathrm{cm}$ shoot $^{-1} \mathrm{~d}^{-1}$ ) as the sum of all leaf growth per shoot that had occurred through the experiment divided by its duration (i.e. 23 d).

\section{Statistical analysis}

The responses of seagrass community metabolism (NCP, R and GCP) and sediment sulfide production and pools to shading were first tested using repeated measures analysis of covariance (ANCOVA), where irradiance was the co-variable, and days since the beginning of the experiment (time) was a fixed factor. Potential pre-conditioning and/or clonal effect in the response of the plants under the different light treatments (i.e. plots) was tested with a repeated measures ANCOVA test for homogeneity-of-slopes and discarded in the absence of interaction to further proceed to the traditional ANCOVA (Statistica 6). The sucrose content (\%) in rhizomes showed a significant interaction effect. Therefore, we used a $t$-test for dependent samples (Statistica 6) to compare the temporal evolution of the percentage of sucrose in rhizomes within each plot. Whenever there was no significant time effect in the variable response to time (GCP, R, NCP, AVS, TRS and SSR), we proceeded to pool the overall data from all sampling events during the shading experiment to gain power in the correlative approach. Data were then plotted by groups of $50 \mu \mathrm{E} \mathrm{m}^{-2} \mathrm{~s}^{-1}$ irradiance. We then used least squares regression analysis on log-transformed variables when required to describe the relationships between variables.

\section{RESULTS}

Average daily irradiances at the canopy level (control treatment) varied significantly over the course of the experiment at the different incubation days, ranging from 168 to $784 \mu \mathrm{E} \mathrm{m}^{-2} \mathrm{~s}^{-1}$. Shading resulted in a decrease in the net oxygen production across the light attenuation gradient by $\sim 4$-fold (see Table S1 in the supplement at www.int-res.com/articles/suppl/ m466p069_supp.pdf), and the Posidonia oceanica meadow at Es Cargol showed resilience in metabolic responses to shading as there were no differences in the responses of $\mathrm{NCP}, \mathrm{GCP}$ or $\mathrm{R}$ rate to irradiance over time (i.e. incubation runs on Days 1, 8, 15 and 23 since the beginning of the experiment; Table S2 in the supplement). Also, the meadow returned to a 
positive NCP within 1 wk following removal of shades (Table $\mathrm{S} 1$ in the supplement), indicating a recovery of the photosynthetic response of the system regardless of the previous shading history of the plots.

Examination of the relationship between community metabolism and irradiance, after pooling the overall NCP response to light irradiance (Fig. 2), indicated that the average $\mathrm{NCP}$ at the maximum daily irradiance (i.e. $784 \mu \mathrm{E} \mathrm{m}^{-2} \mathrm{~s}^{-1}$ ) was $31.1 \mathrm{mmol} \mathrm{O}_{2} \mathrm{~m}^{-2}$ $\mathrm{d}^{-1}$. Corresponding values for GCP and $\mathrm{R}$ were $78.3 \mathrm{mmol} \mathrm{O}_{2} \mathrm{~m}^{-2} \mathrm{~d}^{-1}$ and $47.1 \mathrm{mmol} \mathrm{O}_{2} \mathrm{~m}^{-2} \mathrm{~d}^{-1}$, respectively. The estimated $I_{\mathrm{C}}$ over the linear range
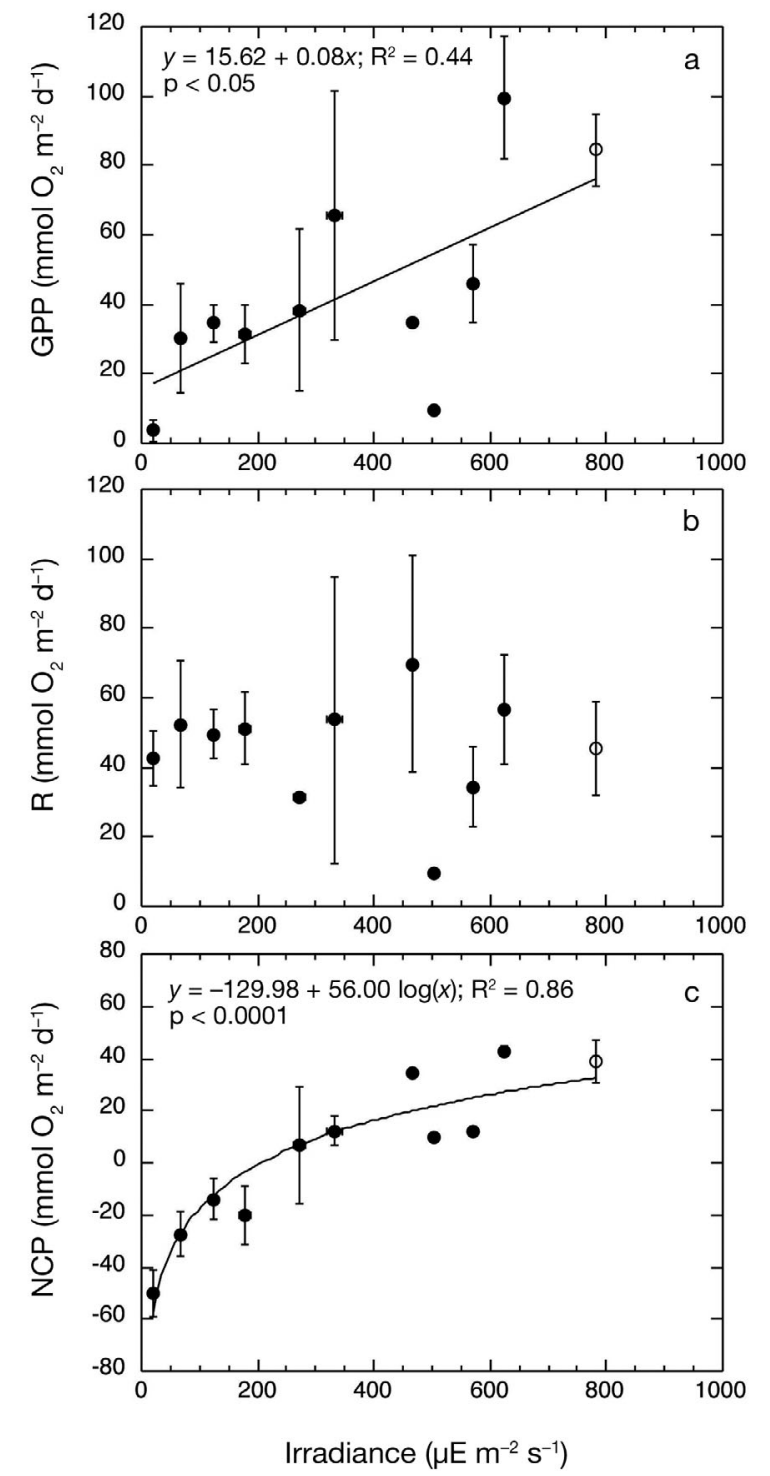

Fig. 2. (a) Gross primary production (GPP), (b) respiration (R) and (c) net community production (NCP) vs. irradiance

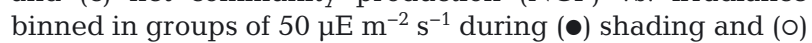
recovery experimental phases. All means $\pm \mathrm{SE}$ of the response (from 0 to $468 \mu \mathrm{E} \mathrm{m}{ }^{-2} \mathrm{~s}^{-1} ; \mathrm{f}(\mathrm{x})=[0.19 \pm$ $0.03 \mathrm{SE}] x-[47.1 \pm 5.96 \mathrm{SE}]$ ) was 248 (range 184 to 338) $\mu \mathrm{E} \mathrm{m}^{-2} \mathrm{~s}^{-1}$, which on average represents $33 \%$ of the maximum irradiance tested.

Overall, the size of the AVS pool and SRR decreased exponentially with increasing irradiance, and they did not vary with time during experimental shading (Fig. 3, Table S2 in the supplement). These effects persisted, as AVS pools and SRR in some previously shaded sediment were still elevated in comparison with control sediments $8 \mathrm{~d}$ after removing the shading screens (Fig. 3, Table S1 in the supplement), although the sediments of control plots also exhibited high SRR during the recovery phase (Table S1). During the shade phase of the experiment, AVS pools and SRR were closely and significantly negatively coupled to NCP (Fig. 4).

The overall sucrose and starch content increased from early May to beginning of June in the control plots (Table S1 in the supplement) as expected from seasonal dynamics of carbohydrate accumulation
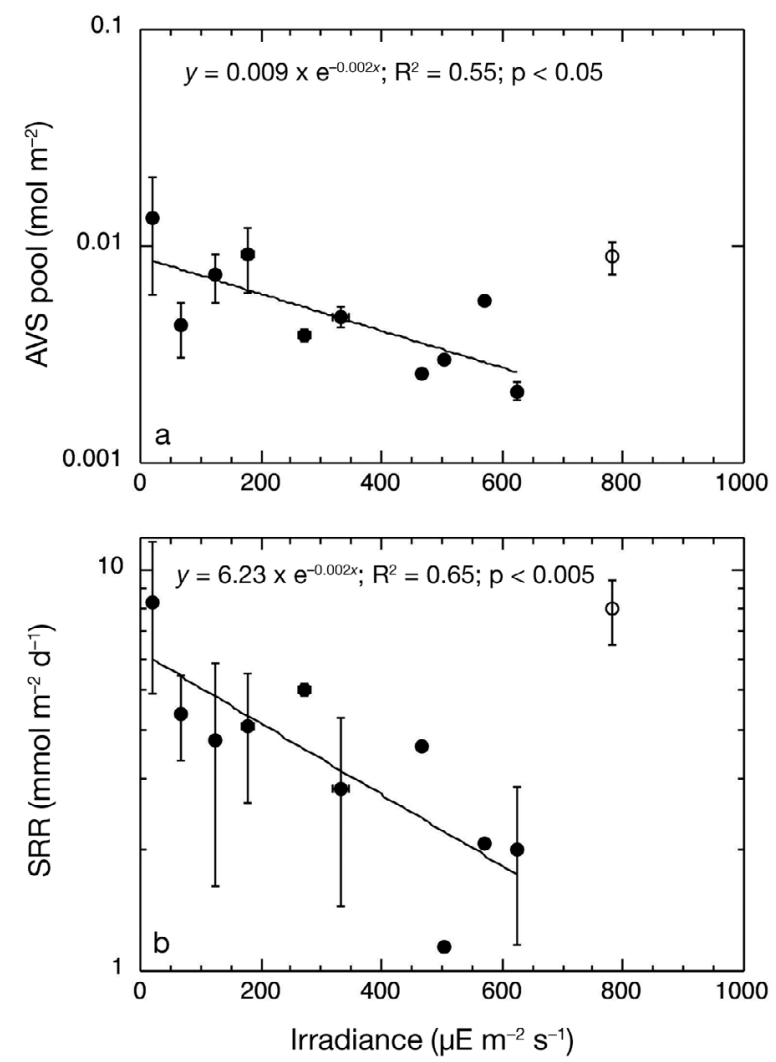

Fig. 3. (a) Acid volatile sulfur pools (AVS pool) and (b) sulfate reduction rates (SRR) in Posidonia oceanica sediments (top $10 \mathrm{~cm}$ ) vs. light irradiance binned in groups of $50 \mu \mathrm{E} \mathrm{m} \mathrm{m}^{-2}$

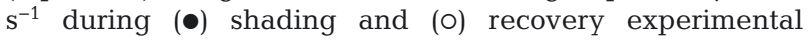
phases. All means \pm SE. The equations correspond to the model fit between AVS pool and SRR and irradiance during shading phase 

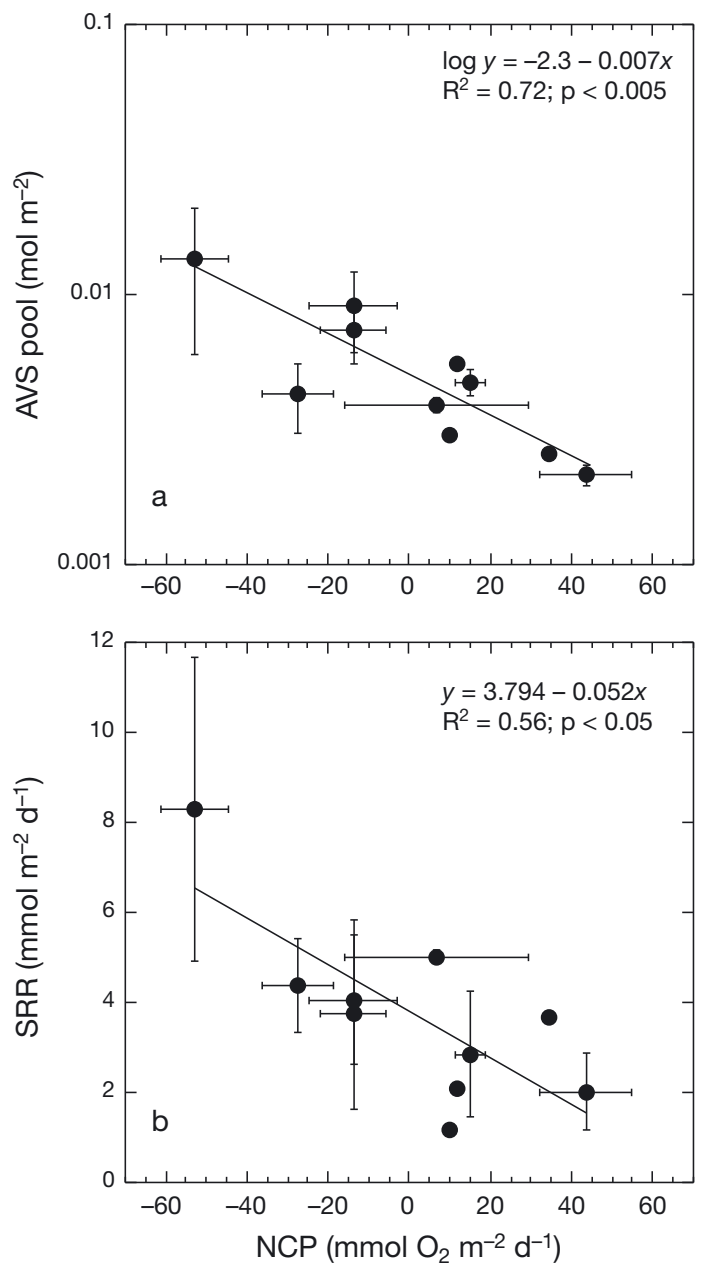

Fig. 4. Relationships between NCP and (a) sediment AVS pool and (B) sediment SRR. Values have been averaged by groups of irradiance of $50 \mu \mathrm{E} \mathrm{m} \mathrm{m}^{-2} \mathrm{~s}^{-1}$. All means \pm SE. AVS pools and SRR are provided for the top $10 \mathrm{~cm}$ of sediment

(Alcoverro et al. 1999). This significant time effect (see Table S2 in the supplement) was already recorded $8 \mathrm{~d}$ after the beginning of the experiment ( $t$-test, p $<0.01$; Fig. 5) in all of the plots receiving $>30 \%$ of the incident light. Differently, plots receiving $12 \% \mathrm{IL}$ did not show any temporal variation in the percentage of sucrose, and the plot receiving only $2 \%$ IL showed a significant decrease in the percentage of sucrose from the initial levels to those recorded $23 \mathrm{~d}$ after shade ( $t$-test, $\mathrm{p}<0.01$; Fig. 5). Differences in the sucrose content with shading remained $8 \mathrm{~d}$ following the removal of the shading screens, resulting in a significant relationship between sucrose content and past irradiance (sucrose content $=0.038 \times($ past IL $\left.)+0.94 ; R^{2}=0.516 ; p<0.01\right)$ indicating that the soluble carbohydrate synthesis and consumption had been affected by shading and were not fully recovered after $1 \mathrm{wk}$ at full irradiance.

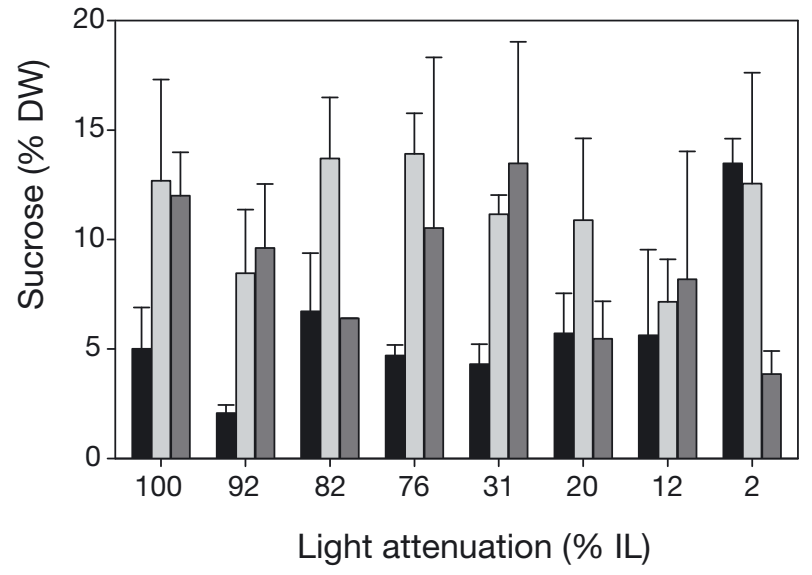

Fig. 5. Temporal evolution of sucrose in young rhizomes (\% sucrose per $g$ dry weight) under different light attenuation. Means $+\mathrm{SE}, \mathrm{n}=3$. Bars: black $=$ initial concentration, light grey $=8 \mathrm{~d}$ after shade, and dark grey $=23 \mathrm{~d}$ after shade

Rhizome starch content did not vary according to the light treatments (see Table S2).

The percentage of nuclei in each phase of the cell cycle across shading treatments and time varied between $56.8 \%$ and $83.8 \%$ nuclei in the G1 phase, $11.92 \%$ and $42.4 \%$ nuclei in the $\mathrm{S}$ phase and $0 \%$ and $7.57 \%$ nuclei in the G2 phase (Table S2 in the supplement). The lowest $(<0.5 \%)$ values in the percentage of nuclei in G2 phase (indicative of the meristematic activity) were observed in the plots receiving $12 \%, 19 \%$ and $92 \%$ of light irradiance after 8 and $15 \mathrm{~d}$ of shading. There was not an effect of time on meristematic activity variability, and the percentage of nuclei in the G1, G2 or S phases was not significantly correlated with light irradiance conditions (Pearson correlation, $\mathrm{p}>0.05$ ). The percentage of nuclei in G2 phase was independent of sediment reducible sulfur pools and sulfate reduction rates (Pearson correlation, $\mathrm{p}>0.05$ ). Similarly, the 4 -fold variability in Posidonia oceanica leaf growth observed across the shading treatments (Table S2 in the supplement) was independent of the light attenuation applied after $3 \mathrm{wk}$ (regression analysis, $\mathrm{p}>0.05$ ).

\section{DISCUSSION}

The seagrass Posidonia oceanica community metabolism clearly responded to the different light treatments during the course of the shading experiment. Throughout time, the irradiances at the control plots were standard for the season and site, including the maximum values. Under such conditions, there was no evidence of saturation of the meadow at Es Car- 
gol, similar to results from in situ incubations in meadows of Thalassia testudinum in the Gulf of Mexico (Herzka \& Dunton 1997, Calleja et al. 2006) and consistent with the notion that self-shading induced by high leaf densities precludes light saturation in dense seagrass meadows (Enríquez \& Pantoja-Reyes 2005, Binzer \& Sand-Jensen 2006).

The multiple measurements of community metabolism throughout the experiment allowed a detailed analysis of the response of a Posidonia oceanica meadow to changing irradiance, particularly at low and intermediate light irradiances, which are the light levels typically underrepresented in experimental studies of seagrass ecosystem response to shade (see review by Leoni et al. 2008). This also allowed a robust estimation of the light compensation point of the community (mean $I_{C}=248$, range from 184 to $338 \mu \mathrm{E} \mathrm{m}^{-2} \mathrm{~s}^{-1}$ ), which in the most conservative scenario represents $40 \%$ of the maximum daily irradiance reached during the experiment and $\sim 3$-fold the $I_{\mathrm{C}}$ estimated for single $P$. oceanica leaves at the same time of the year (Alcoverro et al. 2001). When comparing our results with those from seagrass communities elsewhere, our estimates are similar to those quantified in subtropical systems, such as meadows of Thalasia testudinum from Northern Florida ( $I_{\mathrm{C}}$ from $340 \mu \mathrm{E} \mathrm{m} \mathrm{m}^{-2} \mathrm{~s}^{-1}$ to $107 \mu \mathrm{E} \mathrm{m} \mathrm{m}^{-2} \mathrm{~s}^{-1}$; Calleja et al. 2006 and Herzka \& Dunton 1997, respectively). The encountered variation in the estimates of the light compensation point should be related to meadow functioning heterogeneity but does not take into account differences in ecosystem response along the depth gradient or at different seasons, thus indicating that general expressions of $I_{\mathrm{C}}$ at ecosystem level still require further studies. The NCP and GCP rates encountered lie well within the range of values reported for other $P$. oceanica meadows from the Balearic Islands (Gazeau et al. 2005, Barrón et al. 2006) and mixed meadows of Ruppia maritima and Halodule wrightii in the northern Gulf of Mexico (Stutes et al. 2007, Anton et al. 2009), but they are slightly lower than values reported for communities of Thalassia testudinum in southern Florida (average $\mathrm{NCP}=74.6 \mathrm{mmol} \mathrm{C} \mathrm{m}{ }^{-2} \mathrm{~d}^{-1}$; Calleja et al. 2006). Indeed, NCP may be underestimated in some of our plots (IR $>92 \%$ ) because the estimated $\mathrm{pH}$ inside the incubation bags at the end of the daily incubation deviated from that of the surrounding waters, falling within the range indicative of photosynthesis limitation in P. oceanica (Invers et al. 1997). The maximum $\mathrm{pH}$ differential between the incubation bags and the surrounding waters was $0.49 \mathrm{pH}$ units (from $8.8 \mathrm{in}$ side to 8.2 outside), which represents a $5 \%$ underes- timation of the net photosynthetic rates for the controls during the days of maximum irradiance (Invers et al. 1997). Such effect, however, does not imply changes in the estimation of the compensation point of the system, which is based on the irradiances below light saturation. If present, such an effect would result in an overestimation of the compensation point of the system, which would make our conclusions about the light requirements of the seagrass ecosystem even more conservative than those presented here. Community $\mathrm{R}$ rates are much lower in Mediterranean P. oceanica communities than in trop-

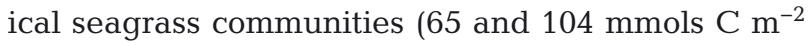
$\mathrm{d}^{-1}$ for tropical seagrass meadows; see Calleja et al. 2006 and Gacia et al. 2005, respectively) reflecting the close coupling of respiration to temperature and the relatively high activation energy of this process (López-Urrutia et al. 2006).

In situ manipulation of the light environment in a shallow Posidonia oceanica meadow at Es Cargol (Mallorca) showed that both net and gross community production decreased with reduced daily light availability, whereas community respiration did not. Further, the photosynthetic response to reduced light irradiance did not change over the duration of the experiment, which indicates a high resistance of the system to photo-acclimation or damage on the photosynthetic apparatus on the main primary producers. This result is coherent with the shade response of single shoots of $P$. oceanica and Amphibolis grifithii for time periods of $<3$ mo (Ruiz \& Romero 2001, Longstaff et al. 1999).

Low light availability enhanced SRR in Posidonia oceanica sediments, reflecting the close link between seagrass community metabolism and activity of sediment sulfate-reducing bacteria. Indeed, a shift from autotrophy to heterotrophy enhanced SRR in the $P$. oceanica sediments by up to 3 -fold. Under intense shading, oxygen production by the primary producers in the community decreases, resulting in a lower diffusion of oxygen from the water column and the roots into the sediment (e.g. Borum et al. 2005). These conditions favor anoxia in the sediment and, thus, SRR. In addition, with low oxygen concentrations in the rhizosphere, seagrass roots might resort to anaerobic metabolic pathways for their respiratory needs and release fermentation products into the sediments that would represent reduced substrates for sulfide-producing bacteria (Calleja et al. 2006). Recovery of SRR in P. oceanica sediments does not appear to be a quick process since SRR remained high in previously shaded plots $1 \mathrm{wk}$ after the plots had been exposed to high irradiance. The $3^{\circ} \mathrm{C}$ 
increase in seawater temperature during the experiment might have prevented a faster reversal to ambient SRR values in shaded plots. The response of SRR to light availability observed here is consistent with results found for a Thalassia testudinum community in the Gulf of Mexico (Calleja et al. 2006). However, the effect of shading on SRR in T. testudinum sediments was much more acute (SRR varying over 2 orders of magnitude) than that observed here. Such contrast might reflect differences in sediment composition (e.g. organic content), seagrass community metabolism, seawater temperature (e.g. Holmer et al. 2003, Koch et al. 2007) and root release of organic compounds between the species.

Shading also had major effects on AVS pools in Posidonia oceanica sediments, with the pools increasing up to 6-fold under the most severe shading. The rapid accumulation of sediment sulfides under shading plausibly results from enhanced SRR and extremely low sediment iron concentration. The sediments of a large part of the Balearic Islands coast, including the seagrass meadow studied here, are rich in carbonate and poor in iron, with iron concentrations ranking amongst the lowest recorded in coastal sediments (Holmer et al. 2003). Due to such extreme scarcity of iron, sulfides accumulate due to sulfate reducers and tend to remain in these sediments, as demonstrated in a $2 \mathrm{yr}$ experiment conducted in a P. oceanica meadow close to Es Cargol (Marbà et al. 2007). As for SRR, AVS pools in previously shaded $P$. oceanica sediments remained high $1 \mathrm{wk}$ after ceasing shading, revealing that sediments exposed to shading were still deteriorated. $P$. oceanica is highly vulnerable to effects by elevated sulfide concentrations, and concentrations $>10 \mu \mathrm{M}$ may already cause meadow decline (Calleja et al. 2007). Our results suggest that anthropogenic activities that decrease seawater light penetration could severely deteriorate seagrass sediment quality (enhancing sulfide pools) and result in important losses of $P$. oceanica ecosystems.

Non-structural carbohydrate (sucrose and starch) contents in young rhizomes at Es Cargol showed levels similar to those reported for other Mediterranean Posidonia oceanica meadows (e.g. Ruiz \& Romero 2001, Gacia et al. 2007). The influence of seasonality was detected in our experiment, as most plots had higher concentrations of non-structural carbohydrates at the end than at the start of the experiment. Throughout the experiment, there was a net consumption of sucrose in the most shaded plot $(<2 \%$ IL), and levels of sucrose remained low in the plots with $<20 \%$ of IL. Similar results with a rapid net sucrose consumption after severe shade but efficient maintenance of sucrose synthesis have been reported in other seagrass species (Longstaff et al. 1999, Lavery et al. 2009, among others), indicating that the consumption of rhizome carbohydrates can serve as an early indicator of severe light impairment stress on seagrass species. Moreover, when carbohydrate synthesis is affected, the recovery of the reserves is slow (see also data for Amphibolis griphithii in Mackey et al. 2007) indicating more vulnerability of the seagrass to consecutive shade events than to isolated shades. In contrast, starch did not respond to shade for a long time, as reported for over 3 mo with <14\% IL in Thalasia testudinum (Lee \& Dunton 1997).

Leaf production rates were not significantly affected by our shading treatments, indicating that carbohydrate reserves in the rhizome might support leaf growth (Alcoverro et al. 2001). This is in accordance with the lack of significant effects of shading on Posidonia oceanica meristematic activity. Clearly, $3 \mathrm{wk}$ of low light availability do not seem sufficient to significantly affect rates of leaf growth and meristematic activity at this time of the year. These results contrast with those obtained by Ruiz \& Romero (2001), who found significant structural impairment in P. oceanica shoots following 1 mo of sustained shading at $10 \%$ of incident light. Our shading treatments only lasted $3 \mathrm{wk}$. Along with a longer period of shading, the lower ambient light availability (i.e. higher water-column light extinction coefficient) typically found for meadows along the Murcia coast in relation to the meadow at Es Cargol could explain the discrepancies between the 2 experiments.

The lack of a significant negative effect of shading on seagrass leaf growth and meristematic activity suggests that our experiment was done during a period when the seagrass is particularly resistant to shading and biomass production can be maintained through rhizome stores (Ott 1979). This, however, may not hold over longer periods of time or at other times in the year as seagrass resistance to shade depends on the time of the year of the light impairment (Lavery et al. 2009). Indeed, the plant may be more sensitive to shading at the end of the winter period, when resource levels stored in the rhizomes reach a minimum (Alcoverro et al. 2001). Similarly, the duration of the experiment does not appear sufficient for the generation of AVS and SRR levels that are detrimental for meristems. Past studies found deleterious AVS and SRR levels that were 2.75- and 1.4-fold higher than the values reported here (Garcias-Bonet et al. 2008). 
In summary, the results presented here provide an estimate for the $I_{\mathrm{C}}$ of Posidonia oceanica at Es Cargol of $338 \mu \mathrm{E} \mathrm{m} \mathrm{m}^{-2} \mathrm{~s}^{-1}$ in the most conservative scenario, which corresponds to $40 \%$ of the maximum daily irradiance reached during the experiment. Gross and net community production was not saturated at the highest irradiances reached, indicating the meadow's primary productivity was light-limited. Shading resulted in increased sediment sulfides, coupled with a parallel decrease in NCP, which confirmed the link between irradiance, sediment conditions and NCP in seagrass meadows. However, the plant's growth and meristematic activity were resistant to our 3 wk of shading, most likely due to trophic support by rhizome stores and because the duration of the experiment was too short to induce depletion of rhizome stores and harmful sulfide concentrations for meristematic activity. Eight days after discontinuing shading, metabolic rates were back to ambient values, but levels of sediment sulfides and rhizome stores still remained affected. Finally, since all of the environmental effects that result in a deterioration of the light environment also result in an increase in the sediment load of particles (either inorganic, organic or both), the resulting increase in the oxygen demand would reinforce the deterioration of the sediment conditions, which was the most sensitive component of the ecosystem to reduced irradiance.

Acknowledgements. This research is a contribution to the project 'Praderas' funded by the Fundación BBVA. We thank R. Martínez, R. Santiago and M. Sánchez for help in the field and the laboratory and M. Calleja and M. Holmer for advice on sulfur analyses. T. Chappuis and A. Lumbreras helped processing of carbohydrate samples. We thank the Instituto Nacional de Meteorología (Spanish Ministry of Environment) for providing global radiation data. N.G.B. was funded by a scholarship from the Government of the Balearic Islands.

\section{LITERATURE CITED}

Alcoverro T, Zimmerman RC, Kohrs DG, Alberte RS (1999) Resource allocation and sucrose mobilization in lightlimited eelgrass Zostera marina. Mar Ecol Prog Ser 187: 121-131

- Alcoverro T, Manzanera M, Romero J (2001) Annual metabolic carbon balance of the seagrass Posidonia oceanica: the importance of carbohydrate reserves. Mar Ecol Prog Ser 211:105-116

Anton A, Cebrián J, Duarte CM, Heck KL, Goff J (2009) Low impact of hurricane Katrina on seagrass community structure and functioning in the northern gulf of México. Bull Mar Sci 85:45-59

Barrón C, Duarte CM (2009) Dissolved organic matter release in a Posidonia oceanica meadow. Mar Ecol Prog Ser 374:75-84
Barrón C, Marbà N, Terrados J, Kennedy H, Duarte CM (2004) Community metabolism and carbon budget along a gradient of seagrass (Cymodocea nodosa) colonization. Limnol Oceanogr 49:1642-1651

Barrón C, Duarte CM, Frankignoulle M, Borges AV (2006) Organic carbon metabolism and carbonate dynamics in a Mediterranean seagrass (Posidonia oceanica) meadow. Estuaries Coasts 29:417-426

Binzer T, Sand Jensen K (2006) Community photosynthesis of aquatic macrophytes. Limnol Oceanogr 51:2722-2733

Borum J, Pedersen O, Greve TM, Frankovich TA, Zieman JC, Fourqurean JW, Madden CJ (2005) The potential role of plant oxygen and sulphide dynamics in die-off events of the tropical seagrass, Thalassia testudinum. J Ecol 93:148-158

Boudouresque JF, Bernard G, Pergent G, Shili A, Verlaque $M$ (2009) Regression of Mediterranean seagrasses caused by natural processes and anthropogenic disturbances and stress: a critical review. Bot Mar 52:395-418

Calleja ML, Barrón C, Hale JA, Frazer TK, Duarte CM (2006) Light regulation of benthic sulfate reduction rates mediated by seagrass (Thalassia testudinum) metabolism. Estuaries Coasts 29:1255-1264

Calleja ML, Marbà N, Duarte CM (2007) The relationship between seagrass (Posidonia oceanica) decline and sulfide porewater concentration in carbonate sediments. Estuar Coast Shelf Sci 73:583-588

> Campbell JE, Fourqurean JW (2011) Novel methodology for in situ carbon dioxide enrichment of benthic ecosystems. Limnol Oceanogr Methods 9:97-109

> Cebrián J, Duarte CM (1998) Patterns in leaf herbivory on seagrasses. Aquat Bot 60:67-82

> Cline JD (1969) Spectrophotometric determination of hydrogen sulfide in natural waters. Limnol Oceanogr 14: $454-458$

Duarte CM (1995) Submerged aquatic vegetation in relation to different nutrient regimes. Ophelia 41:87-112

> Duarte CM, Chiscano CL (1999) Seagrass biomass and production: a reassessment. Aquat Bot 65:159-174

Duarte CM, Amthor JS, DeAngelis D, Joyce LA and others (2003) The limits to models in ecology. In: Canham CD, Cole JJ, Lauenroth WK (eds) Models in ecosystem science. Proc 9th Cary Conf Inst Ecosyst Stud, Millbrook, NY, p 437-451

Duarte CM, Marbà N, Krause-Jensen D, Sánchez-Camacho M (2007) Testing the predictive power of seagrass depth limit models. Estuaries Coasts 30:652-656

> Duarte CM, Marbà N, Gacia E, Fourqurean JW, Beggins J, Barrón C, Apostolaki ET (2010) Seagrass community metabolism: assessing the carbon sink capacity of seagrass meadows. Global Biogeochem Cycles 24:GB4032 doi:10.1029/2010GB003793

> Enríquez S, Pantoja-Reyes NI (2005) Form-function analysis of the effect of canopy morphology on leaf self-shading in the seagrass Thalassia testudinum. Oecologia 145: 234-242

Fossing H, Jørgensen BB (1989) Measurement of bacterial sulfate reduction in sediments: evaluation of a singlestep chromium reduction method. Biogeochemistry 8: 205-222

> Gacia E, Duarte CM, Middelburg JJ (2002) Carbon and nutrient deposition in a Mediterranean seagrass (Posidonia oceanica) meadow. Limnol Oceanogr 47:23-32

Gacia E, Kennedy H, Duarte CM, Terrados J, Marbà N, Papadimitriou S, Fortes M (2005) Light-dependence of 
the metabolic balance of a highly productive Philippine seagrass community. J Exp Mar Biol Ecol 316:55-64

Gacia E, Invers O, Ballesteros E, Manzanera M, Romero J (2007) The impact of the brine from a desalination plant on a shallow seagrass (Posidonia oceanica) meadow. Estuar Coast Shelf Sci 72:579-590

Garcias-Bonet N, Marbà N, Holmer M, Duarte CM (2008) Effects of sediment sulfides on seagrass Posidonia oceanica meristematic activity. Mar Ecol Prog Ser 372:1-6

Gattuso JP, Frankignoulle M, Wollast R (1998) Carbon and carbonate metabolism in coastal aquatic ecosystems. Annu Rev Ecol Syst 29:405-434

> Gazeau F, Duarte CM, Gattuso JP, Barrón C and others (2005) Whole-system metabolism and $\mathrm{CO}_{2}$ fluxes in a Mediterranean Bay dominated by seagrass beds (Palma Bay, NW Mediterranean). Biogeosciences 2:43-60

> Hansen JW, Thamdrup B, Jørgensen BB (2000) Anoxic incubation of sediment in gas-tight plastic bags: a method for biogeochemical process studies. Mar Ecol Prog Ser 208: 273-282

Heip CHR, Goosen NK, Herman PMJ, Krokamp JJ, Middelburg JJ, Soetaert K (1995) Production and consumption of biological particles in temperate tidal estuaries. Oceanogr Mar Biol Annu Rev 33:1-49

> Herzka SZ, Dunton KH (1997) Seasonal photosynthetic patterns of the seagrass Thalassia testudinum in the western Gulf of México. Mar Ecol Prog Ser 152:103-117

> Holmer M, Duarte CM, Marbà N (2003) Sulfur cycling and seagrass (Posidonia oceanica) status in carbonate sediments. Biogeochemistry 66:223-239

> Invers O, Romero J, Pérez M (1997) Effects of pH on seagrass photosynthesis: a laboratory and field assessment. Aquat Bot 59:185-194

Jørgensen BB (1978) A comparison of methods for the quantification of bacterial sulphate reduction in coastal marine sediments. I. Measurement with radiotracer techniques. Geomicrobiol J 1:11-27

Kirk JTO (1983) Light and photosynthesis in aquatic ecosystems. Cambridge University Press, New York, NY

Koch MS, Schopmeyer SA, Holmer M, Madden CJ, KyhnHansen C (2007) Thalassia testudinum response to the interactive stressors hypersalinity, sulfide and hypoxia. Aquat Bot 87:104-110

Lavery PS, McMahon K, Mulligan M, Tennison A (2009) Interactive effects of timing, duration of experimental shading on Amphibolis griffithii. Mar Ecol Prog Ser 394: 21-33

> Lee KS, Dunton KH (1997) Effects of in situ light reduction on the maintenance, growth and partitioning of carbon resources in Thalassia testudinum Banks ex König. J Exp Mar Biol Ecol 210:53-73

Leoni V, Vela A, Pasqualini V, Pergent-Martini C, Pergent G (2008) Effects of experimental reduction of light and nutrient enrichments ( $\mathrm{N}$ and $\mathrm{P}$ ) on seagrasses: a review. Aquatic Conserv 18:202-220

Longstaff BJ, Loneragan NR, O'Donohue MJ, Dennison WC

Editorial responsibility: Matthias Seaman, Oldendorf/Luhe, Germany
(1999) Effects of light deprivation on the survival and recovery of the seagrass Halophila ovalis (R.BR.) Hook. J Exp Mar Biol Ecol 234:1-27

López-Urrutia A, San Martin E, Harris RP, Irigoien X (2006) Scaling the metabolic balance of the oceans. Proc Natl Acad Sci USA 103:8739-8744

Mackey P, Collier CJ, Lavely PS (2007) Effects of experimental reduction of light availability on the seagrass Amphibolis griffithii. Mar Ecol Prog Ser 342:117-126

Marbà N, Duarte CM (2010) Mediterranean warming triggers seagrass (Posidonia oceanica) shoot mortality. Glob Change Biol 16:2366-2375

Marbà N, Hemminga MH, Mateo MA, Duarte CM, Mass Y, Terrados J, Gacia E (2002) Carbon and nitrogen translocation between seagrass ramets. Mar Ecol Prog Ser 226:287-300

> Marbà N, Duarte CM, Díaz-Almela E, Terrados J and others (2005) Direct evidence of imbalanced seagrass (Posidonia oceanica) shoot population dynamics along the Spanish Mediterranean. Estuaries 28:53-62

Marbà N, Holmer M, Gacia E, Barrón C (2006) Seagrass beds and coastal biogeochemistry. In: Larkum AWD, Orth JJ, Duarte CM (eds) Seagrasses: biology, ecology and their conservation. Kluwer Academic Publishers, Dordrecht

Marbà N, Calleja M, Duarte CM, Álvarez E, Díaz-Almela E, Holmer M (2007) Iron additions reduce sulfide intrusion and reverse seagrass (Posidonia oceanica) decline in carbonate sediments. Ecosystems 10:745-756

Ott JA (1979) Persistence of seasonal growth rhythm in Posidonia oceanica (L.) Delile under constant conditions of temperature and illumination. Mar Biol Lett 1:99-104

> Pai SC, Gong GC, Liu KK (1993) Determination of dissolved oxygen in seawater by direct spectrophotometry of total iodine. Mar Chem 41:343-351

> Prado P, Alcoverro T, Romero J (2010) Nutrient status, plant availability and seasonal forcing mediate fish herbivory in temperate seagrass beds. Mar Ecol Prog Ser 409: 229-239

$>$ Roland F, Caraco NF, Cole JJ (1999) Rapid and precise determination of dissolved oxygen by spectrophotometry: evaluation of interference from colour and turbidity. Limnol Oceanogr 44:1148-1154

Ruiz JM, Romero J (2001) Effects of in situ experimental shading on the Mediterranean seagrass Posidonia oceanica. Mar Ecol Prog Ser 215:107-120

> Serrano O, Mateo MA, Renom P (2011) Seasonal response of Posidonia oceanica to light disturbances. Mar Ecol Prog Ser 423:29-38

Stutes J, Cebrián J, Stutes AL, Hunter A, Corcoran AA (2007) Benthic metabolism across a gradient of anthropogenic impact in three shallow coastal lagoons in NW Florida. Mar Ecol Prog Ser 348:55-70

Yemm EW, Willis AJW (1954) The estimation of carbohydrates in plant extracts by anthrone. Biochem J 57: 508-514

Submitted: October 24, 2011; Accepted: July 6, 2012

Proofs received from author(s):October 5, 2012 